\title{
A giant pregnancy-associated intra-abdominal desmoid tumour: not necessarily a contraindication for subsequent pregnancy
}

\author{
Eelco de Bree ${ }^{1 *}$, Eustathios Dimitriadis ${ }^{1}$, Elpida Giannikaki ${ }^{2}$, Evangelia G Chryssou ${ }^{3}$ and John Melissas ${ }^{1}$
}

\begin{abstract}
Desmoid tumours are rare mesenchymal tumours, often locally invasive and characteristically associated with a high local recurrence rate after resection. A potential aetiological role for female hormones is indicated. Pregnancy-associated desmoid tumours are almost exclusively located in the abdominal wall. An essential issue is how to counsel women who have had a pregnancy-associated desmoid tumour and subsequently wish to bear a child. A considerably rare case of a patient with a resection of a giant pregnancy-associated, $33 \mathrm{~cm}$ in diameter, intra-abdominal desmoid tumour is presented. After a subsequent pregnancy, the patient delivered healthy twins 26 months later. Fifty-four months after treatment, there are no signs of recurrent or second desmoid tumour. Although rarely located in the abdomen, pregnancy-associated desmoid tumours should be included in the differential diagnosis of intra-abdominal tumours detected during or shortly after pregnancy. Based on this case and a few others reported in the literature, subsequent pregnancy does not necessarily seem to be a risk factor for recurrent or new disease.
\end{abstract}

Keywords: Aggressive fibromatosis, Desmoid tumour, Intra-abdominal tumour, Pregnancy

\section{Background}

Desmoid tumour, also called aggressive or desmoid-type fibromatosis, is a rare monoclonal, fibroblastic proliferation. Although histologically benign and unable to give rise to metastases, desmoids are often locally invasive and characteristically associated with a high local recurrence rate after resection. While this fibroblastic disorder may be observed in nearly every part of the body, desmoids occur most commonly in extremities. Intraabdominal location is observed only in a small proportion of patients [1].

Aetiology of desmoid tumours is incompletely defined. Numerous acknowledged factors are associated with their development [1]. Increased incidence occurring during and after pregnancy, as well as following use of oral contraceptives, the preponderance of women of reproductive age in many series, anecdotal reports of spontaneous tumour regression during menopause, expression of oestrogen beta receptor and reports of

\footnotetext{
* Correspondence: debree@edu.uoc.gr

${ }^{1}$ Department of Surgical Oncology, Medical School of Crete University

Hospital, Heraklion, Greece

Full list of author information is available at the end of the article
}

tumour regression with anti-oestrogen treatment are all factors which indicate a potential aetiological role for female sex hormones [1,2]. Pregnancy-associated desmoids are almost exclusively located in the abdominal wall $[2,3]$. Herein we report on a young woman with a giant intraabdominal desmoid tumour diagnosed 3 weeks after giving birth and resected soon afterwards. The location of a pregnancy-associated desmoid tumour in the abdomen is unusual. Further, due to hormonal influences, a subsequent pregnancy may theoretically be a risk factor for a second desmoid or recurrent disease. Neither during nor after the subsequent pregnancy was recurrence or development of a second desmoid tumour observed in our case. The literature on this topic is herein reviewed.

\section{Case presentation}

A 31-year-old woman presented with persistent abdominal distension 3 weeks after vaginal delivery of a healthy daughter. It had been her first pregnancy. She was breast-feeding her baby. Her medical history was unremarkable and she had had neither trauma nor any abdominal operation in the past. At physical examination

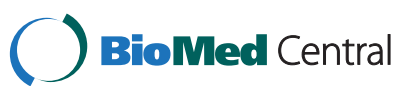



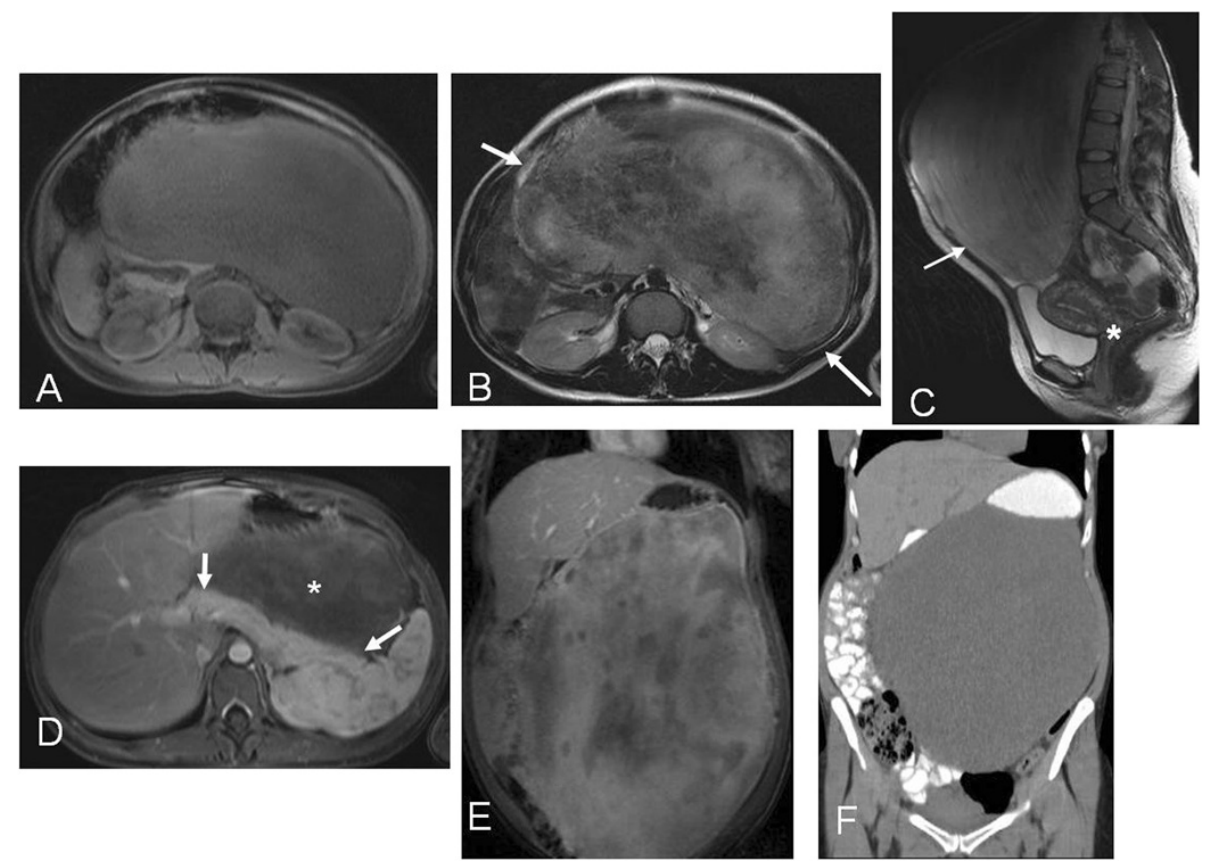

Figure 1 Radiological images. (A) Unenhanced T1-weighted MRI shows large, almost homogeneous, well-defined, intermediately low signal intensity mass, occupying the abdominal cavity, displacing solid organs and bowel loops. (B, C) T2-weighted MRI depicts heterogeneously hyperintense mass (arrows), with prominent areas of low signal intensity and unrelated to the bladder and uterus (asterisk). (D, E) Gadoliniumenhanced T1-weighted MRI shows no intervening fat planes between homogeneously enhancing pancreas (arrows) and slowly and heterogeneously enhancing tumour (asterisk), with intervening low signal intensity areas. (F) Unenhanced CT demonstrates the mass displacing opacified bowel loops.

intra-abdominal mass was found. Laboratory tests were normal. Computed tomography $(\mathrm{CT})$ and magnetic resonance imaging (MRI) demonstrated a huge solid intraabdominal soft tissue mass, which occupied most of the peritoneal cavity and which had displaced anatomical structures such as the liver, the pancreas and the small and large intestine (Figure 1). Chest CT showed no evidence of metastatic disease. CT-guided core needle biopsy revealed a mesenchymal, probably myofibroblastic, lesion whose biological behaviour could not be determined.

At laparotomy, a large intra-abdominal mass was observed (Figure 2). The transversal colon and its mesocolon were stretched over the frontal side of the tumour and fixed to the mass (Figure 2). While its caudal side was mobile (Figure 3), the cranial side of the tumour was fixed focally to the inferior part of the tail of the pancreas (Figure 4). There was no infiltration of other organs. The tumour with the transverse colon, its mesocolon and a wide rim of the tail of the pancreas was resected en bloc. An end-to-end anastomosis of the ascending with the descending colon was performed. The postoperative course was uneventful. The tumour weighed $6.2 \mathrm{~kg}$ and was $33 \times 29 \times 8.5 \mathrm{~cm}$ in size. Histological examination demonstrated a mesenteric desmoid tumour (Figure 5) which had actually infiltrated the transverse colon as well as the surface of the resected part of the pancreas. The tumour appeared to have been excised completely. Immunohistochemical staining for oestrogen receptor alpha and progesterone was negative. No pathology was seen in the resected colon.

The patient did not receive any adjuvant treatment. She became spontaneously pregnant, despite the recommendation that she postpone pregnancy to allow for a 2-year disease-free follow-up period. Nevertheless, she delivered

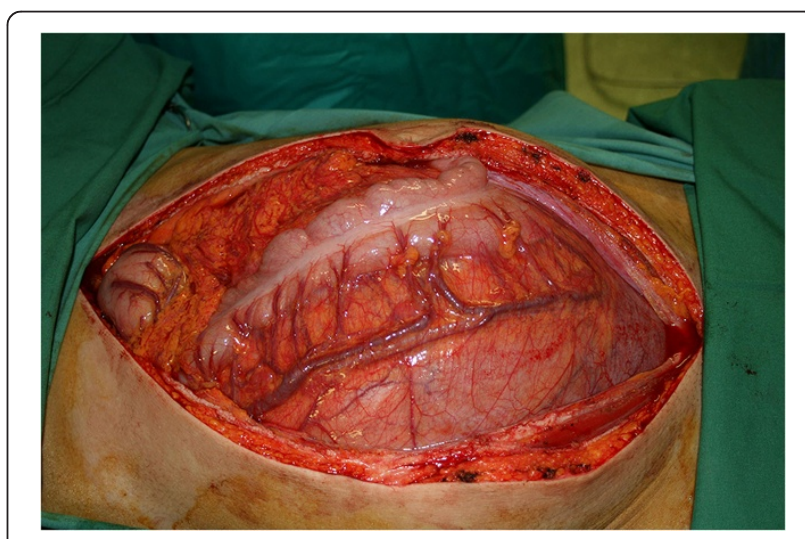

Figure 2 Findings at laparotomy. An enormous intra-abdominal tumour was seen adjacent to the overlying transverse colon and its mesocolon. 


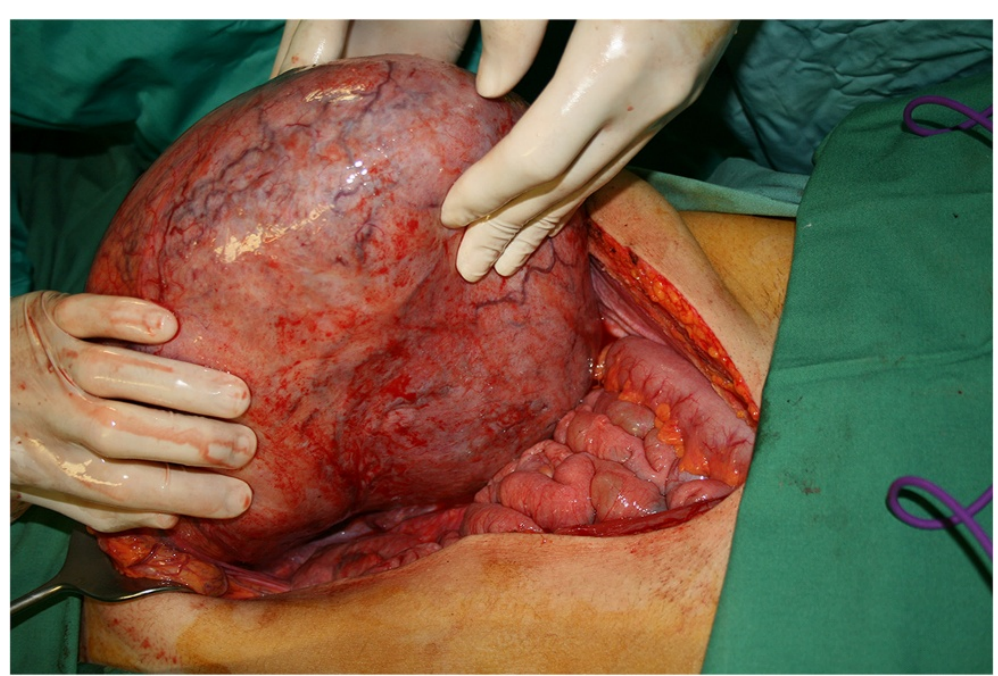

Figure 3 Intraoperative findings. Caudally the tumour was mobile and did not involve small bowel loops or pelvic organs.

healthy twins by Caesarean section 26 months after initial treatment for the desmoid tumour. Fifty-four months after resection of the desmoid, she is in excellent condition without any sign of tumour recurrence on abdominal sonography and MRI, or of development of a second desmoid tumour.

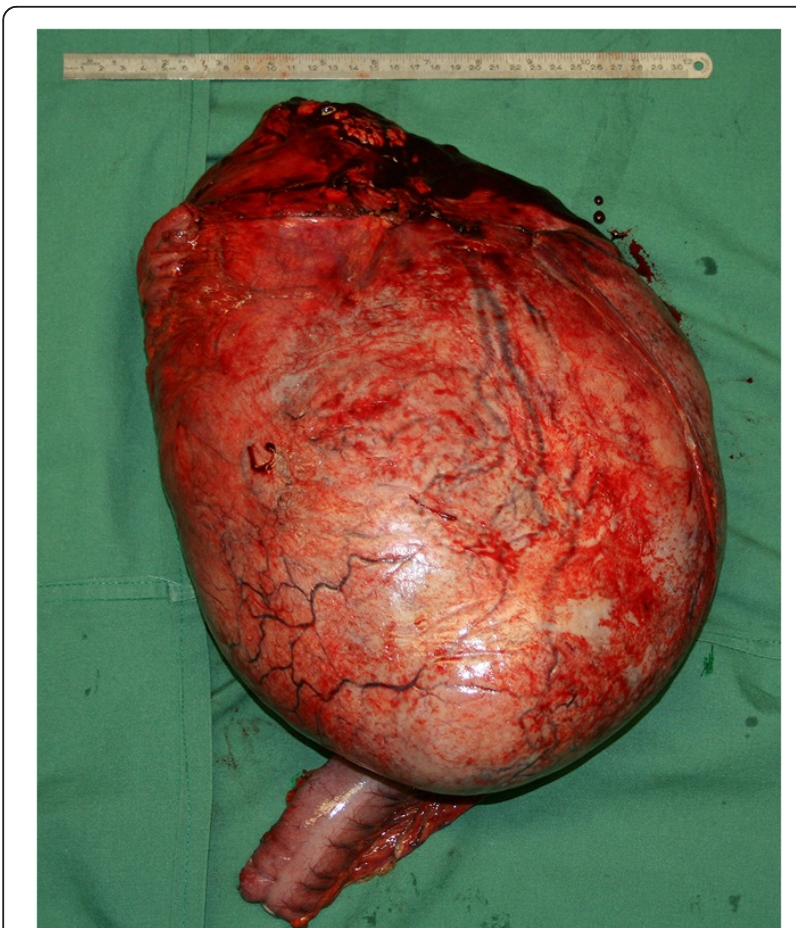

Figure 4 The surgical specimen. Dorsal view of the specimen of the giant tumour shows the resected rim of pancreatic tail at the cranial base of the tumour (at the top of the figure). The resected transverse colon overlying the tumour at the frontal site is partially visible.

\section{Discussion}

The enormous tumour size in the present case is noteworthy. Primary desmoids $>30 \mathrm{~cm}$ in size have only incidentally been reported [4-6]. It remains remarkable that the tumour was not observed at routine repetitive sonography during pregnancy. The optimal treatment of desmoids remains difficult to be determined, due to the rarity, the heterogeneity and the very unpredictable natural history of the disease. Therefore, an individualized approach is warranted [1]. Surgical resection has most commonly been used, while radiotherapy, medical treatment and watchful waiting are alternative options [1].

Typically, desmoids arising during or shortly after pregnancy are almost always located in the abdominal wall $[2,3]$. Such an association with pregnancy has very rarely

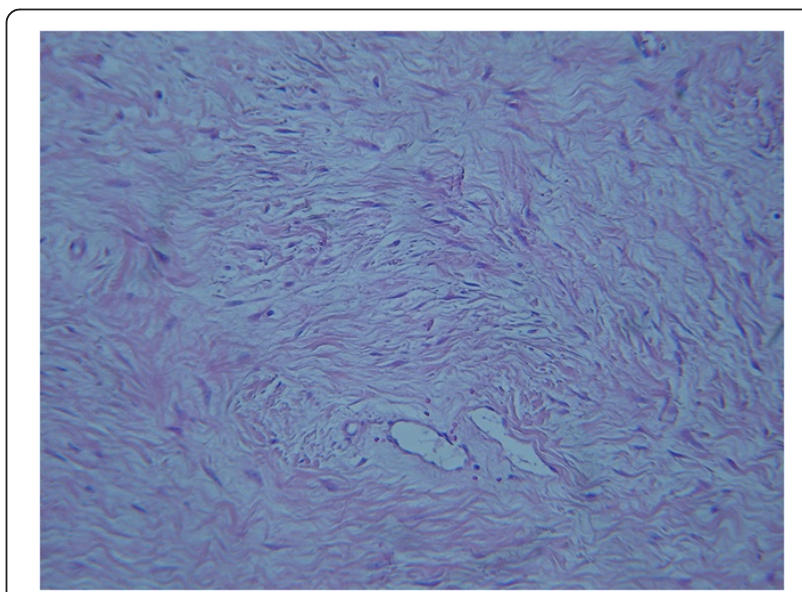

Figure $\mathbf{5}$ Histological findings. Microscopically the tumour was composed of bland, spindle or stellate mesenchymal cells, without obvious atypia or increased mitotic index. The cells were arranged haphazardly in a dense fibrous stroma with thick walled vessels $(H \& E, \times 100)$. 
Table 1 Reports of pregnancy-associated desmoid tumours located outside the abdominal wall

\begin{tabular}{|c|c|c|c|c|c|c|}
\hline First author & Year & $\begin{array}{l}\text { Patient's } \\
\text { age } \\
\text { (years) }\end{array}$ & Site of origin & Size $(\mathrm{cm})$ & $\begin{array}{l}\text { Time of } \\
\text { diagnosis }\end{array}$ & Treatment and outcome \\
\hline Ober [10] & 1955 & 18 & Popliteal space & 3 & $\begin{array}{l}17 \text { weeks } \\
\text { of gestation }\end{array}$ & $\begin{array}{l}\text { Excision on the } 12 \text { th postpartum day; free of } \\
\text { recurrence } 1 \text { year later }\end{array}$ \\
\hline Allen [7] & 1997 & 19 & Vulva & 3 & $\begin{array}{l}5-6 \text { weeks } \\
\text { of gestation }\end{array}$ & $\begin{array}{l}\text { Incomplete excision; excision of recurrence after } \\
2 \text { months; second recurrence after several months, } \\
\text { treated by excision and radiotherapy }\end{array}$ \\
\hline Gherman [8] & 1999 & 25 & Larynx & 2.3 & $\begin{array}{l}20 \text { weeks } \\
\text { of gestation }\end{array}$ & $\begin{array}{l}\text { Incomplete excision; recurrence after } 8 \text { weeks; } \\
\text { spontaneous complete regression } 9 \text { weeks } \\
\text { after delivery }\end{array}$ \\
\hline Sportiello [11] & 1991 & 40 & Retroperitoneum & 10 & $\begin{array}{l}10 \text { days } \\
\text { after C.S. }\end{array}$ & $\begin{array}{l}\text { Excision + hormonal therapy, recurrence after } \\
12 \text { months, excision of recurrence + radiotherapy, } \\
\text { rapidly second recurrence, complete response for } \\
27+\text { months with hormonal treatment }\end{array}$ \\
\hline Firoozmand [15] & 2001 & 27 & Ileoanal pouch & 17 & $\begin{array}{l}23 \text { weeks } \\
\text { of gestation }\end{array}$ & $\begin{array}{l}\text { At } 23 \text { weeks gestation complete resection, outcome } \\
\text { not reported }\end{array}$ \\
\hline Wang [9] & 2006 & 27 & Neck & 2 & $\begin{array}{l}\text { 2nd month } \\
\text { of gestation }\end{array}$ & One month after complete excision no recurrence \\
\hline Sun [12] & 2007 & 28 & Mesentery & 12 & $\begin{array}{l}\text { Immediately } \\
\text { after c.S. }\end{array}$ & One year after complete excision no recurrence \\
\hline Tankshali [16] & 2011 & 28 & $\begin{array}{l}\text { Pelvis } \\
\text { (retroperitoneal) }\end{array}$ & 12 & During C.S. & One year after complete excision no recurrence \\
\hline Ilhan [13] & 2012 & 22 & Mesentery & 7 & $\begin{array}{l}2 \text { months } \\
\text { postpartum }\end{array}$ & $\begin{array}{l}\text { Radical excision along with small bowel segment, } \\
\text { outcome not reported }\end{array}$ \\
\hline Present case & 2013 & 31 & $\begin{array}{l}\text { Transverse } \\
\text { mesocolon }\end{array}$ & 33 & $\begin{array}{l}3 \text { weeks } \\
\text { postpartum }\end{array}$ & Fifty-four months after resection no recurrence \\
\hline
\end{tabular}

c.s. $=$ Caesarean section.

been observed in other locations (Table 1). Single cases of desmoid tumour arising in the vulva [7], larynx [8], neck [9] and popliteal space [10] during pregnancy have been described, while only a few cases of pregnancy-associated intra-abdominal desmoids, originating from the retroperitoneum [11], mesentery [12,13] and pelvis $[14,15]$ have been reported. In one report [14], a pelvic desmoid tumour interfered both with normal maturation and delivery of the fetus as well as the patient's ability to void and defecate, prompting surgical intervention at 23 weeks of gestation. Following the resection the patient delivered a healthy full-term baby. In the other pelvic

Table 2 Reports of patients diagnosed with pregnancy-associated desmoid tumour and subsequent pregnancy

\begin{tabular}{|c|c|c|c|c|c|c|}
\hline First author & Year & $\begin{array}{l}\text { Patient's } \\
\text { age } \\
\text { (years) }\end{array}$ & Site of origin & $\begin{array}{l}\text { Size } \\
(\mathrm{cm})\end{array}$ & Diagnosis and treatment & Subsequent pregnancy and outcome \\
\hline Caldwell [17] & 1976 & 26 & Abdominal wall & 17.5 & $\begin{array}{l}\text { Shortly after birth of fourth } \\
\text { child, observation }\end{array}$ & $\begin{array}{l}\text { Almost complete regression in size during and after } \\
\text { subsequent pregnancy }\end{array}$ \\
\hline Ezra [19] & 1990 & 35 & Abdominal wall & $\begin{array}{l}2,7 \\
\text { and } 4\end{array}$ & $\begin{array}{l}\text { Recurrence after prior } \\
\text { excision, wide resection } \\
\text { of the area with } 3 \text { local } \\
\text { recurrences }\end{array}$ & $\begin{array}{l}\text { Subsequent pregnancy }>2 \text { years after resection. } \\
\text { No new recurrence during and shortly } \\
\text { after pregnancy }\end{array}$ \\
\hline \multirow[t]{2}{*}{ Way [18] } & 1999 & 28 & Abdominal wall & 4 & $\begin{array}{l}\text { Immediately after } \\
\text { birth of second child, } \\
\text { wide resection }\end{array}$ & $\begin{array}{l}\text { Miscarriage, delivery of healthy child and abortion } \\
\text { respectively 15, } 24 \text { and } 39 \text { months after resection. } \\
\text { No recurrence } 60 \text { months after resection }\end{array}$ \\
\hline & & 28 & Abdominal wall & 2 & $\begin{array}{l}\text { Twelve months after } \\
\text { pregnancy, wide resection }\end{array}$ & $\begin{array}{l}\text { Subsequent pregnancy } 13 \text { months after tumour } \\
\text { excision. No recurrence } 46 \text { months after resection }\end{array}$ \\
\hline Galeotti [16] & 2006 & 31 & Abdominal wall & 10 & After first pregnancy, observation & $\begin{array}{l}\text { Increase in diameter from } 6 \text { to } 10 \mathrm{~cm} \text { during second } \\
\text { pregnancy, excision of the tumour after transvaginal } \\
\text { delivery. No data of further follow-up }\end{array}$ \\
\hline Present case & 2013 & 31 & $\begin{array}{l}\text { Transverse } \\
\text { mesocolon }\end{array}$ & 33 & $\begin{array}{l}\text { Three weeks postpartum, } \\
\text { resection }\end{array}$ & $\begin{array}{l}\text { Delivery of twins } 26 \text { months after resection. } \\
\text { No recurrence } 54 \text { months after resection }\end{array}$ \\
\hline
\end{tabular}


desmoid case [15], the tumour obstructed labour, necessitating a Caesarean section and subsequent tumour excision. In our patient, the intra-abdominal desmoid tumour evidently grew rapidly, reaching its enormous dimensions due to hormonal stimulation during pregnancy. The giant tumour had no apparent adverse influence on the fetus and its vaginal delivery, possibly because the desmoid originated from the transversal mesocolon. Although only a few cases have been reported, desmoid tumour should be included in the differential diagnosis of intra-abdominal tumours detected during or shortly after pregnancy.

An essential issue is how to counsel women who have been diagnosed with a pregnancy-associated desmoid and subsequently wish to have a child. Only a small number of case reports provide some data regarding this issue (Table 2). During subsequent pregnancy an untreated pregnancy-associated desmoid tumour of the abdominal wall demonstrated volumetric increase of the tumour, necessitating surgical resection in one patient [16], while there was significant regression without treatment in another case [17]. As in the present case, the only three other patients reported with a subsequent pregnancy after surgical treatment for their pregnancyassociated desmoid demonstrated no recurrence or second desmoid tumour $[18,19]$. Hence, a subsequent pregnancy does not necessarily seem to be a risk factor for recurrent or new disease. Nevertheless, a follow-up period of at least 2 years before planning a subsequent pregnancy may be advisable, since the median time to desmoid recurrence after resection is approximately 1 to 2 years, as is reported in large series [4,20-22].

\section{Conclusions}

Although pregnancy-associated desmoid tumours are almost exclusively located in the abdominal wall, desmoid tumour should be included in the differential diagnosis of intra-abdominal tumours detected during or shortly after pregnancy. From the sparse literature data and from the case herein presented it seems that subsequent pregnancy is not necessarily a risk factor for recurrent or new desmoid tumour. Based on the median time to eventual desmoid recurrence after resection, it may be advisable for the patient to allow for a 2-year follow-up period before planning an eventual subsequent pregnancy.

\section{Consent}

Written informed consent was obtained from the patient for publication of this case report and any accompanying images. A copy of the written consent is available for review by the Editor-in-Chief of this journal.

\section{Competing interests}

The authors declare that they have no competing interests.

\section{Authors' contributions}

$\mathrm{EdB}$ and $\mathrm{ED}$ collected the information, reviewed the literature and wrote the manuscript. EdB, ED, EG, EGC and JM participated in analyzing the data. EG carried out the pathological studies and provided the histological figure. EGC interpreted and provided the radiological images. EdB and JM edited the article. All authors read and approved the final manuscript.

\section{Acknowledgments}

We would like to thank Mrs. Eugenia Bolbasis for linguistically reviewing the manuscript.

\section{Author details}

${ }^{1}$ Department of Surgical Oncology, Medical School of Crete University Hospital, Heraklion, Greece. ${ }^{2}$ Department of Pathology, Medical School of Crete University Hospital, Heraklion, Greece. ${ }^{3}$ Department of Radiology, Medical School of Crete University Hospital, Heraklion, Greece.

Received: 24 June 2013 Accepted: 19 September 2013 Published: 16 October 2013

\section{References}

1. de Bree E, Keus R, Melissas J, Tsiftsis DD, van Coevorden F: Desmoid tumors: need for an individualized approach. Expert Rev Anticancer Ther 2009, 9:525-535.

2. Johner A, Tiwari $\mathrm{P}$, Zetler $\mathrm{P}$, Wiseman SM: Abdominal wall desmoid tumors associated with pregnancy: current concepts. Expert Rev Anticancer Ther 2009, 9:1675-1682.

3. Carneiro C, Hurtubis C, Sing M, Robinson W: Desmoid tumor of the right rectus abdominus muscle in postpartum women. Arch Gynecol Obstet 2009, 279:869-873

4. Lev D, Kotilingam D, Wei C, Ballo MT, Zagars GK, Pisters PWP, Lazar AA, Patel SR, Benjamin RS, Pollock RE: Optimizing treatment of desmoid tumors. J Clin Oncol 2007, 25:1785-1791.

5. Lee Y-C, Lee J-W: Innovative treatment of a huge nuchal desmoids tumour: a case report with a 2-year follow-up. J Plast Reconstr Aesth surg 2010, 63:e622-e626.

6. Fakhar S, Qazi MP, Saeed G, Ashraf M, Tariq N: Successful removal of a huge pelvic desmoid tumor. Taiwan J Obstet Gynecol 2010, 49:361-363.

7. Allen MV, Novotny DB: Desmoid tumor of the vulva associated with pregnancy. Arch Pathol Lab Med 1997, 121:512-514.

8. Gherman RB, Bowen E, Eggleston MK, Karakla D: Desmoid tumor of the larynx complicating pregnancy: a case report. Am J Obstet Gynecol 1999, 180:1036-1037.

9. Wang C-P, Chang Y-L, Ko J-Y, Cheng CH, Yeh CF, Lou PJ: Desmoid tumor of the head and neck. Head Neck 2006, 28:1008-1013.

10. Ober WB, Velardo JT, Greene RT, Taylor RJ: Desmoid tumor of the popliteal space occurring during pregnancy: report of a case with bioassays. J Natl Cancer Inst 1955, 16:569-577.

11. Sportielli DJ, Hoogerland DL: A recurrent pelvic desmoid tumor successfully treated with tamoxifen. Cancer 1991, 67:1443-1446.

12. Sun $L$, Wu H, Zhuang $Y-Z$, Guan $Y$-S: A rare case of pregnancy complicated with mesenteric mass: What does chylous ascites tell us? World J Gastroenterol 2007, 13:1632-1635.

13. Ihan E, Yakan S, Sahin T, Cengiz T, Denecli AG: Mesenteric fibromatosis in a postpartum patient: a case report. Surg Chron 2012, 17:114-146.

14. Firoozmand E, Prager E: Pelvic desmoid tumor: threat to mother and fetus. Am Surg 2001, 67:1213-1215.

15. Tankshali R, Srivastava S, Anshuman K, Shah M: An unusual presentation of aggressive fibromatosis (retroperitoneal desmoidtumour) in pelvic cavity presented as obstructed labour. J Indian Med Assoc 2011, 109:589-591.

16. Galeotti F, Facci E, Bianchini E: Desmoidtumour involving the abdominal rectus muscle: report of a case. Hernia 2006, 10:278-281.

17. Caldwell EH: Desmoid tumor: musculoaponeurotic fibrosis of the abdominal wall. Surgery 1976, 79:104-106.

18. Way JC, Culham BA: Desmoidtumour. The risk of recurrent or new disease with subsequent pregnancy: a case report. Can J Surg 1999, 42:51-54.

19. Ezra Y, Krausz MM, Rivkind A, Anteby SO: Successful pregnancy and normal delivery after Marlex replacement of the abdominal wall. Am J Obstet Gynecol 1990, 162:97-98. 
20. Smith AJ, Lewis JJ, Merchant NB, Leung DHY, Woodruff JM, Brennan MF: Surgical management of intra-abdominal desmoidtumours. Br J Surg 2000, 87:608-613.

21. Ballo MT, Zagars GK, Pollack A, Pisters PWT, Pollack RA: Desmoid tumor: Prognostic factors and outcome after surgery, radiation therapy, or combined surgery and radiation therapy. J Clin Oncol 1999, 17:158-167.

22. Phillips SR, A'Hern RA, Thomas JM: Aggressive fibromatosis of the abdominal wall, limbs and limb girdles. Br J Surg 2004, 91:1624-1629.

doi:10.1186/1477-7819-11-277

Cite this article as: de Bree et al:: A giant pregnancy-associated intraabdominal desmoid tumour: not necessarily a contraindication for subsequent pregnancy. World Journal of Surgical Oncology 2013 11:277.

\section{Submit your next manuscript to BioMed Central and take full advantage of:}

- Convenient online submission

- Thorough peer review

- No space constraints or color figure charges

- Immediate publication on acceptance

- Inclusion in PubMed, CAS, Scopus and Google Scholar

- Research which is freely available for redistribution 